\title{
STUDY OF SODIUM, POTASSIUM, AND CALCIUM SALTS INFLUENCE ON PROTEIN STABILITY BY DIFFERENTIAL SCANNING CALORIMETRY
}

\section{ИЗУЧЕНИЕ ВЛИЯНИЯ СОЛЕЙ НАТРИЯ, КАЛИЯ И КАЛЫЦИЯ НА СТАБИЛЬНОСТЬ БЕЛКОВ МЕТОДОМ ДИФФЕРЕНЦИАЛЬНОИ СКАНИРУЮЩЕИ КАЛОРИМЕТРИИ}

\author{
Tunieva E. K., ${ }^{1}$ Dederer I., ${ }^{2}$ \\ 1 - The V.M. Gorbatov All-Russian Meat Research Institute, Moscow, Russia \\ ${ }^{2}$ - Max Rubner Institute (MRI), Kulmbach. Germany
}

Ключевые слова: дифференциальная сканирующая калориметрия, актин, миозин, температура денатурации белков

\begin{abstract}
Аннотащия
Изучение стабильности белков в зависимости от различных технологических факторов позволяет направленно корректировать физико-химические свойства мяса и качество готовой продукции. В статье представлены возможности использования ДСК для изучения влияния моно- и дивалентных солей на стабильность белков к термической обработке. С иелью установления влияния хлорида натрия и его заменителей - солей калия и кальция на термостабильность белков были проведены исследования измельченных образияов длиннейшей мышиы свинины, посоленных поваренной солью в количестве 2,0\% и композиииями солей с пониженным на 50\% содержанием хлорида натрия - смесь хлоридов натрия и калия; смесь хлоридом натрия, калия и кальция на дифференииальном сканирующем калориметре DSC Q 2000, с пределами изменения температур от $5{ }^{\circ} \mathrm{C}$ до $100{ }^{\circ} \mathrm{C}$ и скоростью изменения температуры - 1 К/мин. Установлено, что внесение хлорида калия взамен 50\% поваренной соли не оказывало существенного влияния на стабильность актина и миозина к тепловой денатурации. Посол мяса композицией со смесью хлоридов натрия, калия и кальизя приводил к снижению устойчивости миофибриллярных белков, что свидетельствовало о дестабилизирующем эффекте кальиия на актин и миозин. Выявлена отрицательная корреляиионная зависимость между величиной ионной силь и температурой денатурации миозина и актина. Коэффициенты корреляици составили для миозина - минус 0,99, для актина - минус 0,95. Снижение температуры денатурации миобибриллярных белков в присутствии хлорида кальиия открывает перспективы для проведения исследований, направленных на обоснование возможности проведения тепловой обработки мясной продукиии с пониженным содержанием натрия при более низких температурах.
\end{abstract}

\section{Введение}

Исследованию свойств белковых компонентов мясного сырья посвящено немало научных работ отечественных и зарубежных ученых. Однако, большинство методов, используемых для изучения физико-химических изменений белков в процессе созревания и технологической обработки мяса, основаны на предварительной экстракции белковых веществ различными растворителями, что существенно усложняет проведение исследований и увеличивает их трудоемкость. В связи с этим представляет интерес изучение возможности
Keywords: differential scanning calorimetry, actin, myosin, protein denaturation temperature

\section{Abstract}

Study of protein stability depending on the various technological factors allows to directionally adjust the physicochemical properties of raw meat and the quality of finished meat products. The paper investigates the possibility of using the DSC to study the influence of monovalent and divalent salts on protein thermal stability. In order to determine the effect of sodium chloride and its substitutes, potassium and calcium salts, on the thermal stability of proteins, the studies were carried out with grinded pork longissimus muscle samples salted with sodium chloride at level of $2.0 \%$ and with salt compositions containing reduced by 50\% level of sodium chloride (a mixture of sodium and potassium chlorides; a mixture of sodium, potassium, and calcium chlorides) using the differential scanning calorimeter DSC Q 2000 in the temperature range of $5{ }^{\circ} \mathrm{C}$ to $100{ }^{\circ} \mathrm{C}$ and the temperature change rate of $1 \mathrm{~K} / \mathrm{min}$. It was found that the addition of potassium chloride instead of $50 \%$ of sodium chloride had no significant effect on actin and myosin resistance to thermal denaturation. Meat salting using the mixture of sodium, potassium, and calcium chlorides resulted in decrease of myofibrillar proteins stability indicating the destabilizing effect of calcium on actin and myosin. A negative correlation between the magnitude of the ionic strength and the temperature of myosin and actin denaturation has been found. The correlation coefficients were minus 0.99 and minus 0.95 for myosin and actin respectively. Reduction of denaturation temperature for myofibrillar proteins in the presence of calcium chloride opens perspectives to study the possibility of heat treatment at lower temperatures for meat products with reduced sodium content

\section{Introduction}

Many scientific works of national and foreign scientists studied the properties of protein components in meat raw materials. However, most of the methods used to study the physical and chemical changes of proteins during meat ageing and processing are based on preliminary extraction of proteins with various solvents, which considerably complicates the research and increases labor input. In this context, it is interesting to study the possibility of thermal analysis (calorimetry) usage to determine physical and chemical changes in biological components of meat, i.e. protein and fat. Thermodynamic 
использования метода термического анализа (калориметрии) для изучения физико-химических изменений биологических компонентов мяса - белков и жиров. Термодинамические свойства мяса имеют важную роль для оптимизации параметров технологических процессов, в том числе охлаждения и замораживания [1]. Исследования термодинамических характеристик различных видов мяса, проведенные зарубежными учеными, позволили установить пики термограмм, соответствующие температуре денатурации миозина (54-58 $\left.{ }^{\circ} \mathrm{C}\right)$, актина $\left(71-83^{\circ} \mathrm{C}\right)$ и коллагена $\left(67^{\circ} \mathrm{C}\right)$ с помощью дифференциальной сканирующей калориметрии (ДСК) [2-5]. Однако ряд исследований, проведенных в последние годы, свидетельствуют о существенном влиянии на формирование термодинамических характеристик мясных систем различных рецептурных ингредиентов - поваренной соли, пищевых фосфатов, стабилизаторов полисахаридной природы, белковых препаратов и др. [610]. Так, большинство исследований свидетельствовало о смещении температуры денатурации белков мяса в присутствии поваренной соли в сторону низких температур. Согласно работе Thorarinsdottir и др., соответствующий пик трансформации актина трески смещался от 73,5 до $67,0^{\circ} \mathrm{C}$ [7]. Fiala и Honikel установили снижение температуры денатурации и энтальпии миофибрилярных белков мышечной ткани говядины, посоленной хлоридом натрия [11]. Схожие данные были получены Kijowski и др., которые зафиксировали смещение температуры денатурации миозина с 58,4 до $53,6{ }^{\circ} \mathrm{C}$ и актина от 80,7 до $64,0^{\circ} \mathrm{C}$, в результате внесения хлорида натрия в количестве до 40 г/л в экстракт мышечных белков [3].

Однако, несмотря на важную роль поваренной соли в процессе посола и влияние ее на формирование потребительских характеристик и микробиологическую стабильность мясной продукции необходимо отметить тенденцию к снижению содержания хлорида натрия в мясных продуктах за рубежом. С целью сокращения дозировки поваренной соли в мясной продукции интерес представляет использование солей, не содержащих натрий, но способных восполнить функциональные свойства поваренной соли, в том числе соленый вкус и технологические характеристики (активность воды, влагосвязывающая способность и т.д.) $[12,13]$.

Принимая во внимание влияние различных дозировок хлорида натрия на стабильность белков к тепловой денатурации, а также учитывая возрастающую мировую тенденцию к снижению содержания поваренной соли в мясных продуктах, целью данной работы являлось изучение влияния композиций солей с пониженным содержанием натрия на температуру денатурации белковых молекул методом ДСК.

\section{Материалы и методы}

Объектами исследований служили образцы длиннейшей мышцы свинины II категории, породы крупная белая женских особей 2-х годовалого возраста, измельченные на волчке через отверстия решетки 2-3 мм и посоленные поваренной солью в количестве 2,0\% и композициями солей № 1 и № 2 в количестве адекватном внесению $2,0 \%$ хлорида натрия. Для посола мяса использовали соль поваренную пищевую по ГОСТ Р 51574, хлорид калия properties of meat have an important role in optimization of parameters of technological processes including cooling and freezing [1]. Using differential scanning calorimetry (DSC), in studies of thermodynamic characteristics of different meat types carried out by foreign scientists thermogram peaks were determined corresponding to denaturation of myosin (54$\left.58^{\circ} \mathrm{C}\right)$, actin $\left(71-83^{\circ} \mathrm{C}\right)$, and collagen $\left(67^{\circ} \mathrm{C}\right)[2-5]$. However, in recent years a number of studies showed that the formation of thermodynamic characteristics of different meat systems are significantly influenced by ingredients in formulation, i.e. sodium chloride, phosphates, stabilizer polysaccharides, protein preparations, etc. [6-10]. So, most of the research had the evidence of protein denaturation temperature shift to lower temperatures in the presence of sodium chloride. According to Thorarinsdottir et al., corresponding actin transformation peak for cod shifted from 73.5 to $67.0^{\circ} \mathrm{C}$ [7]. Fiala and Honikel have found the reduction of denaturation temperature and enthalpy for myofibrillar proteins of beef muscle tissue salted with sodium chloride [11]. Similar data were obtained by Kijowski et al., which registered the shift of denaturation temperature from 58.4 to $53.6^{\circ} \mathrm{C}$ and from 80.7 to $64.0^{\circ} \mathrm{C}$ for myosin and actin respectively as a result of sodium chloride addition to the extract of the muscle proteins in an amount of up to $40 \mathrm{~g} / \mathrm{L}$ [3].

Despite the important role of sodium chloride in salting process and its influence on the formation of consumer characteristics and microbiological stability of meat products, overseas there is a trend for reduction of its content in meat products. In order to reduce the level of sodium chloride in meat products the usage of salts containing no sodium, but still possessing its functional properties including the salty taste and technological characteristics (water activity, water binding capacity, etc.) is of significant interest $[12,13]$.

Taking into account the effect of different levels of sodium chloride on the resistance of proteins to heat denaturation and considering the increasing global trend to reduce the sodium chloride content in meat products, the aim of this work was to study the effect of salt compositions with reduced sodium content on the temperature of protein molecules denaturation by DSC.

\section{Materials and methods}

The objects of research were samples of second grade pork longissimus muscle from Large White females in the age of 2 years. The samples were ground in mincing machine with 2 to $3 \mathrm{~mm}$ grid and salted with sodium chloride at the level of $2.0 \%$ and with compositions of salts No. 1 and No. 2 at levels corresponding to $2.0 \%$ of sodium chloride. Table salt according to GOST R 51574, potassium chloride (analytically pure), and calcium chloride dihydrate (analytically pure) were used for meat salting. Salted meat was stored at $4 \pm 2{ }^{\circ} \mathrm{C}$ for 2 days. In order to study the influence of salt substitutes on meat protein resistance to thermal denaturation salted samples were studied by differential scanning calorimetry. Calorimetry is a method for studying the physical and chemical processes based on the detection of thermal effects accompanying the transformation of substances in the conditions of temperature programming. This method allows to register the heating (or cooling) curves of the tested object, during the phase transformation of which component (mixture of components) the heat is emitted or 
(химически чистый), хлорид кальция двухводный (химически чистый). Посоленное мясо хранили при температуре $4 \pm 2{ }^{\circ} \mathrm{C}$ в течение 2 сут. Для изучения характера влияния заменителей соли на стабильность белков мяса к тепловой денатурации, были проведены исследования посоленных образцов методом дифференциальной сканирующей калориметрии. Калориметрия - метод исследования физико-химических процессов, основанный на регистрации тепловых эффектов, сопровождающих превращения веществ в условиях программирования температуры. Этот метод позволяет фиксировать кривые нагревания (или охлаждения) исследуемого объекта, при фазовом превращении одного из компонентов (смеси компонентов) которого происходит выделение или поглощение теплоты и на кривой (термограмме) появляются изломы (пики). В основе дифференциального метода лежит метод сравнения температур между измеряемым образцом и эталоном - термически стабильным материалом, без фазовых переходов, с температурой плавления (денатурации) значительно выше интервала температур, в котором проводятся исследования [14]. Исследования проводили на дифференциальном сканирующем калориметре DSC Q 2000 фирмы TA Instruments. Для проведения анализа были использованы алюминиевые тигли. Пределы изменения температур от $5^{\circ} \mathrm{C}$ до $100{ }^{\circ} \mathrm{C}$, скорость изменения температуры - 1 К/мин. Изменение энтальпии, т.е. энергию, необходимую для денатурации белка, представляющую собой площадь пика, рассчитывали по формуле:

$$
\Delta H=\frac{60}{\beta} \int_{t 1}^{t 2} \frac{d Q}{d t} d T
$$

где $\Delta \mathrm{H}$ - энтальпия, Дж/г;

$\mathrm{Q}$ - количество теплоты, Вт

$\beta$ - постоянная скорость нагревания, К/мин;

$\mathrm{t}$ - время, $\mathrm{c}$.

\section{Результаты и их обсуждение.}

Учитывая многофункциональность поваренной соли при производстве мясной продукции, в том числе существенное ее влияние на вкусовые характеристики готового продукта, снижение хлорида натрия повлечет за собой ухудшение органолептических и функциональных свойств мясных продуктов, и как следствие снижение конкурентоспособности продукции. По этой причине были проведены предварительные исследования, позволившие оценить целесообразность замены $\mathrm{NaCl}$ другими хлоридами, в первую очередь калия и кальция, с учетом их влияние на вкус, влагосвязывающую способность и активность воды. На основании предварительных исследований были предложены композиции с пониженным на 50\% содержанием натрия (композиция № 1 - смесь хлорида натрия и хлорида калия; композиция № 2 - смесь хлоридов натрия, калия и кальция).

Разработанные композиции использовали для посола мяса и определения стабильности белков к тепловой денатурации.

Согласно полученной в рамках исследований термограмме (рис. 1) в свинине, посоленной хлоридом натрия в количестве $2,0 \%$, было зафиксировано три пика - absorbed and peaks appear on the curve (thermogram). The differential method is based on the temperature comparison between measured sample and reference, thermally stable material, without phase transition and with melting (denaturation) point that is significantly higher than the temperature range of the study [14]. Investigations were carried out using the differential scanning calorimeter DSC Q 2000 from TA Instruments company. Aluminum bowls were used for analysis. Limits of temperature changes were $5{ }^{\circ} \mathrm{C}$ to $100{ }^{\circ} \mathrm{C}$ and the temperature change rate was $1 \mathrm{~K} / \mathrm{min}$. The change of enthalpy, the energy needed for denaturation of the protein, which is a peak area, was calculated by the formula:

$$
\Delta H=\frac{60}{\beta} \int_{t 1}^{t 2} \frac{d Q}{d t} d T
$$

where $\Delta \mathrm{H}$ is enthalpy, $\mathrm{J} / \mathrm{g}$;

$\mathrm{Q}$ - quantity of heat, W;

$\beta$ - constant of heating rate, $\mathrm{K} / \mathrm{min}$;

$\mathrm{t}$ - time, $\mathrm{s}$.

\section{Results and discussion}

Given the multifunctionality of sodium chloride in manufacturing of meat products including its significant impact on flavor characteristics of final product, reduction of sodium chloride would result in a deterioration in sensory and functional properties of meat products, and, as a consequence, in lowering of product competitiveness. For this reason, preliminary research has been carried out allowing to evaluate the feasibility of $\mathrm{NaCl}$ replacing with other chlorides, first of all, potassium and calcium chlorides, regarding their impact on taste, water binding capacity, and water activity. Based on preliminary studies, compositions with $50 \%$ reduced sodium content (composition No. 1 - mixture of sodium chloride and potassium chloride; composition No. 2 - mixture of sodium, potassium and calcium chlorides) have been proposed.

Developed composition were used for salting of meat and for determination of proteins resistance to heat denaturation.

According to thermogram obtained under study (Figure 1), in pork salted with sodium chloride at level of $2.0 \%$ there were three peaks $-30.98^{\circ} \mathrm{C}$ (I), $48,85^{\circ} \mathrm{C}$ (II), and $66.24{ }^{\circ} \mathrm{C}$ (III) corresponding to fat melting point (I), temperature of myosin denaturation (II) and actin denaturation (III) respectively.

Partial replacement of sodium chloride with potassium chloride did not lead to significant change in fat melting point, as well as in the values of temperature peaks typical for myosin and actin denaturation. However, it is worth noting that the addition of potassium chloride contributed to increase in enthalpy of thermal transitions of myofibrillar proteins (Figure 2), which is associated with more power for the denaturation of proteins when using salting composition No. 1 .

Addition of composition with calcium chloride instead of sodium chloride initiated the decrease of myosin and actin denaturation temperature, while the thermogram of meat salted with this composition had smoothing of peak typical for myosin denaturation, thus indicating a decrease in the enthalpy of thermal transition as compared to samples salted with sodium chloride and with composition No.1. Furthermore, the addition of calcium chloride resulted in reduction of the temperature range, in which actin 
Table 1. Salt compositions with reduced sodium content

Таблица 1. Композиции солей с пониженным содержанием натрия

\begin{tabular}{|l|c|c|}
\hline \multirow{2}{*}{ Substitutes | Наименование солезаменителей } & \multicolumn{2}{|c|}{ Salt level, \% | Дозировки солей, \% } \\
\cline { 2 - 3 } & Composition No. 1 | Композиция 1 & Сomposition No. 2 | Композиция 2 \\
\hline Sodium chloride $(\mathrm{NaCl}) \mid$ Хлорид натрия $(\mathrm{NaCl})$ & 1.0 & 1.0 \\
\hline Potassium chloride $(\mathrm{KCl}) \mid$ Хлорид калия $(\mathrm{KCl})$ & 1.2 & 0.6 \\
\hline Calcium chloride $\left(\mathrm{CaCl}_{2}\right) \mid$ Хлорид кальция $\left(\mathrm{CaCl}_{2}\right)$ & - & 0.8 \\
\hline
\end{tabular}

$30,98^{\circ} \mathrm{C}(\mathrm{I}), 48,85^{\circ} \mathrm{C}$ (II) и $66,24^{\circ} \mathrm{C}$ (III), что соответствовало температуре плавления жира (I), температуре денатурации миозина (II) и актина (III).

Частичная замена поваренной соли на хлорид калия не приводила к существенному изменению температуры плавления жира, а также значения температурных пиков, характерных для денатурации миозина и актина. Однако стоит отметить, что внесение хлорида калия способствовало увеличению энтальпии тепловых переходов миофибриллярных белков (рис. 2), что связано с требованием большего количества энергии для денатурации белков при посоле мяса композицией 1.

Внесение композиции с хлоридом кальция взамен поваренной соли инициировало снижение температуры денатурации миозина и актина, причем на термограмме мяса, посоленного данной композицией, наблюдалось сглаживание пика, характерного для денатурации миозина, что свидетельствовало о снижении энтальпии теплового перехода по сравнению образцами, посоленными хлоридом натрия и композицией 1. Кроме того, в результате внесение хлорида кальция при посоле мяса зафиксировано уменьшение интервала температур, при котором происходили денатурационные изменения актина, что также приводило к снижению энтальпии денатурации актина. Так, если для образцов, посоленных поваренной солью и композицией 1 интервал температур фазового перехода составил $-11,0 \pm 1,0{ }^{\circ} \mathrm{C}$, то при посоле композицией 2 , содержащей хлорид кальция данный показатель уменьшился до $6,0 \pm 1,0{ }^{\circ} \mathrm{C}$. Таким образом, для денатурации миофибриллярных белков при посоле композицией солей, содержащей кальций, требовалось меньшее количество энергии по сравнению с традиционным посолом мяса, что свидетельствует о дестабилизирующем влиянии ионов кальция на белковые молекулы. Полученные данные согласовывались с работами StarbusvikE. и др., установившими дестабилизирующий эффект кальция на миофибриллярные белки говядины [12].

Дестабилизирующий эффект хлорида кальция на миофибриллярные белки, вероятно, объясняется ускорением протеолиза под действием ионов кальция, таким образом денатурационные изменения начинаются до тепловой обработки, в связи с чем уменышается энергия, необходимая для обеспечения тепловой денатурации миозина и актина. Кроме того, внесение хлорида кальция приводит к снижению рН мяса, приближая его к изоэлектрической точке, при

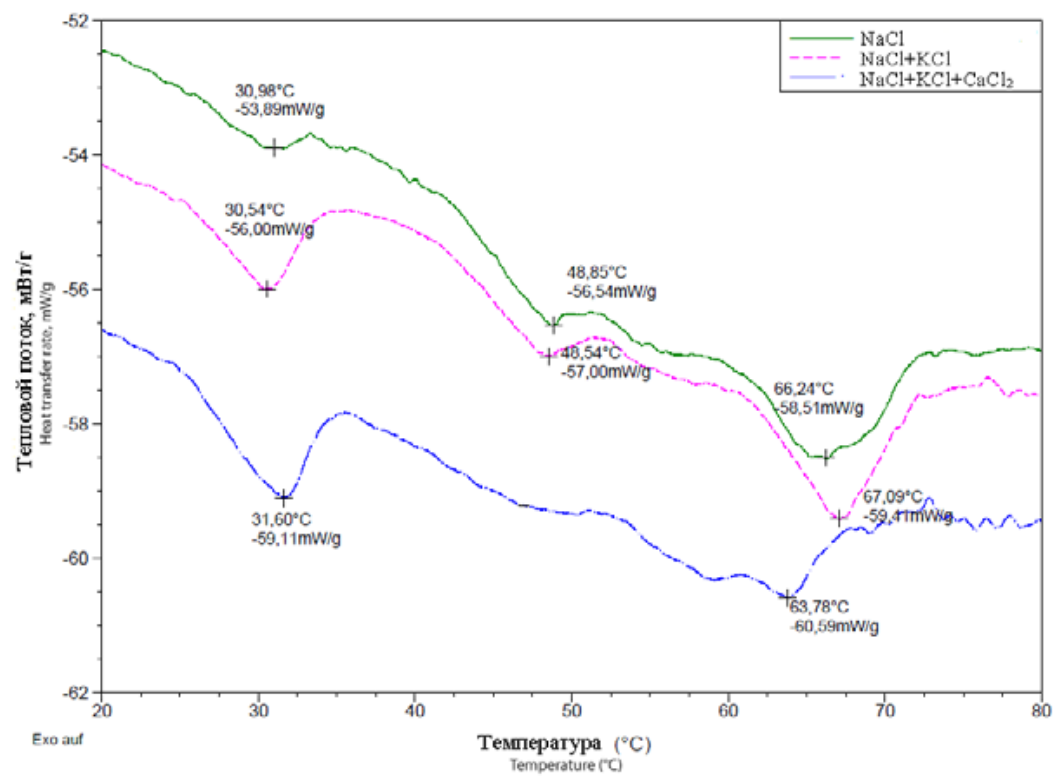

Рис. 1 Температура денатурации белков в присутствии солей

Figure 1 Temperature of proteins denaturation in the presence of salts

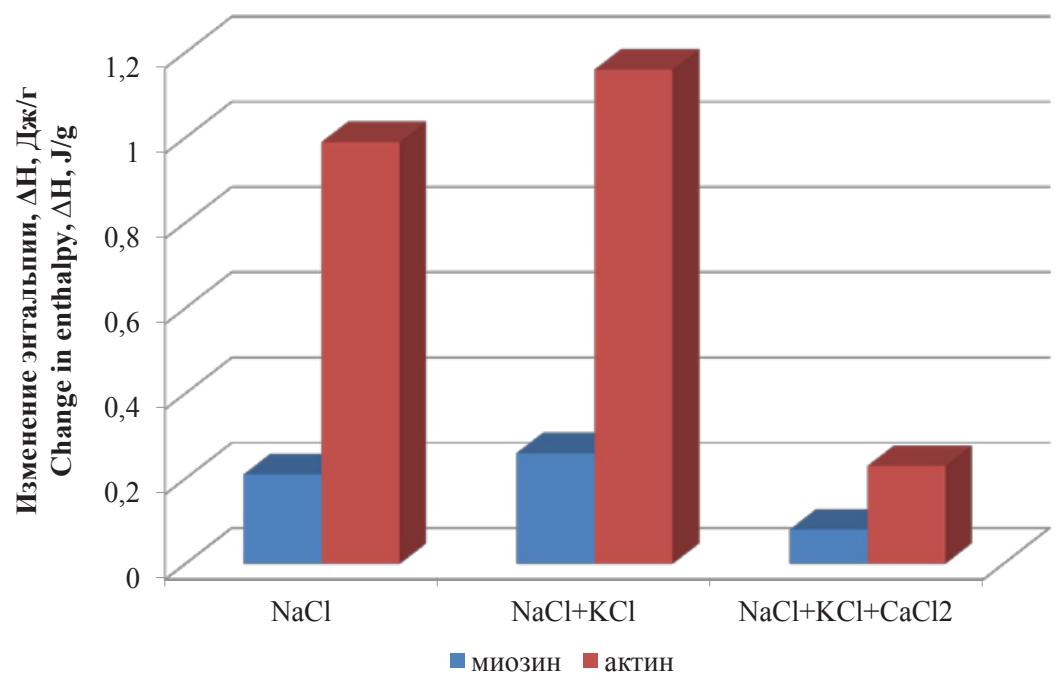

Рис. 2 Изменение энтальпии денатурации белков в присутствии разных солей Figure 2 Protein denaturation enthalpy change in the presence of various salts 
которой белки наименее устойчивы. Еще одним возможным объяснением влияния хлорида кальция на снижение стабильности белков к тепловой обработке является его влияние на увеличение ионной силы. Математическая обработка полученных данных показала, что изменение температуры денатурации белков с увеличением ионной силы, создаваемой за счет внесения моно- и дивалентных солей происходило по экспоненциальному закону:

$$
Y=a e^{b x}
$$

где:

Y - температура денатурации белка, соответствующая значению пика на термограмме ${ }^{\circ} \mathrm{C}$;

$\mathrm{x}$ - ионная сила, создаваемая за счет внесения солей, моль/л;

a, b - коэффициенты экспоненциальной функции.

Анализ полученных данных подтвердил наличие отрицательной корреляционной зависимости между величиной ионной силы и температурой денатурации миозина и актина - абсолютная величина коэффициентов корреляции составила минус 0,99 и минус 0,95 соответственно.

\section{Выводы}

Исследования денатурационных изменений белков с помощью дифференциальной сканирующей калориметрии расширяют научные представления о характере действия моно- и дивалентных солей на термостабильность основных миофибриллярных белков - миозина и актина. Термограмма посоленного мяса позволила зафиксировать три пика, соответствующих температуре плавления жира, температуре денатурации миозина и актина. В ходе проведенных исследований установлено, что использование для посола мяса взамен 50\% поваренной соли хлорида калия не приводило к существенному изменению температуры денатурации миофибриллярных белков с одновременным увеличением энтальпии тепловых переходов миозина - на 0,05 Дж/г и актина - на 0,17 Дж/г.

Посол мяса с использованием композиции солей, содержащей хлорид кальция, приводил к снижению температуры денатурации актина до $63,78^{\circ} \mathrm{C}$ и сглаживанию пика, соответствующего для денатурации миозина, а также уменьшению энергии, необходимой для тепловых переходов миофибриллярных белков, в том числе за счет сокращения интервала температур денатурационных изменений. Таким образом, очевидно, что особенности влияния ионов кальция на физико-химические и биохимические свойства мяса - снижение $\mathrm{pH}$, увеличение ионной силы, ускорение протеолитических изменений, обуславливают его дестабилизирующий эффект на тепловую устойчивость белковых молекул. На основании полученных данных установлены коэффициенты корреляции между величиной ионной силы и температурой денатурации миозина и актина - минус 0,99 и минус 0,95 соответственно.

Полученные результаты по снижению стабильности белков в процессе посола мяса представляют интерес для обоснования оптимальных режимов тепловой обработки мясной продукции с пониженным содержанием натрия.
The destabilizing effect of calcium chloride on myofibrillar proteins is probably due to proteolysis acceleration because of calcium ions activity. Thus, denaturation begins prior to heat treatment, therefore decreasing the energy required for heat denaturation of actin and myosin. Furthermore, the addition of calcium chloride reduces the $\mathrm{pH}$ of meat moving it closer to isoelectric point, at which the proteins are least stable. Another possible explanation for the influence of calcium chloride on decrease of protein resistance to heat treatment is its effect on increase in ionic strength. The mathematical processing of the obtained data shows that the change in the temperature of proteins denaturation with increasing ionic strength due to addition of monovalent and divalent salts is exponential:

$$
Y=a e^{b x}
$$

where:

$\mathrm{Y}$ - denaturation temperature corresponding to peak value on the thermogram, ${ }^{\circ} \mathrm{C}$;

$\mathrm{x}$ - ionic strength created by addition of salts, mole/L;

$a, b-$ the coefficients of exponential function.

Data analysis confirmed the existence of a negative correlation between the magnitude of ionic strength and the temperature of myosin and actin denaturation; the absolute value of the correlation coefficient was minus 0.99 and minus 0.95 respectively.

\section{Conclusion}

Research of denaturation changes in proteins by differential scanning calorimetry expands scientific understanding of the nature of monovalent and divalent salts action on thermal stability of main myofibrillar proteins, myosin and actin. Thermogram of salted meat allowed to register three peaks corresponding to fat melting point and denaturation temperatures of actin and myosin. During the research it was found that the usage of meat salting with potassium chloride instead of $50 \%$ of sodium chloride did not lead to significant changes in denaturation temperature of myofibrillar proteins with simultaneous increase in thermal transitions enthalpy of myosin and actin by $0.05 \mathrm{~J} / \mathrm{g}$ and $0.17 \mathrm{~J} / \mathrm{g}$ respectively.

Meat salting using the compositions containing calcium chloride resulted in decrease of actin denaturation temperature to $63.78{ }^{\circ} \mathrm{C}$, in smoothing of peak corresponding to myosin denaturation, and in reduction of energy required for thermal transitions of myofibrillar proteins, particularly by reducing the temperature range of denaturation changes. Thus, it is obvious that the influence of calcium ions on the physicochemical and biochemical properties of meat, i.e. lowering the $\mathrm{pH}$, ionic strength increase, proteolytic changes accelerating, causes its destabilizing effect on the thermal stability of protein molecules. Based on the data received, correlation coefficients between the ionic strength and denaturation temperature of myosin and actin are determined as minus 0.99 and minus 0.95 respectively.

The results for reduction of proteins stability during the meat salting are of interest to study the optimum heat treatment conditions of meat products with reduced sodium content. 


\section{БЛБЛИОГРАФИЧЕСКЛЙ СПИСОК}

1. Karunakar, B. Specific heat and thermal conductivity of shrimp meat / B. Karunakar, S.K. Mishra, S. Bandyopadhyay // Journal of Food Engineering. - 1998. - Vol. 37(3), p.345-351. 2. Stabursvik, E. Thermal denaturation of proteins in post rigor muscle tissue as studied by differential scanning calorimetry/ $E$. Stabursvik, H. Martens// Journal of the Science of Food and Agriculture - 1980. - Vol. 31, p. 1034-1042

3. Kijowski, J. M. Effect of sodium chloride and phosphates on the thermal properties of chicken meat proteins/ J. M. Kijowski, M.G. Mast// Journal of Food Science - 1988. - Vol. 53 (2), p. 367-370

4. Graiver, N. Diffusion of sodium chloride in pork tissue/ $\mathbf{N}$. Graiver, A. Pinotti, A.Califano, N. Zaritzki// Journal of Food Engineering. - 2006. - Vol. 77, p. 910-918.

5. Sasaki, K. Differential scanning calorimetry of porcine adipose tissues/ K. Sasaki, M. Mitsumoto, T. Nishioka, M. Irie // Meat Science. - 2006. - Vol. 72(4), p. 789-792.

6. Raemy, A. Behavior of foods studied by thermal analysis: Introduction / A. Raemy// J Thermal AnalCalorimetry. - 2003. Vol. 71(1), p.273-278.

7. Thorarinsdottir, K. A. Changes in myofibrillar proteins during processing of salted cod (Gadusmorhua) as determined by electrophoresis and differential scanning calorimetry / K. A. Thorarinsdottir, S. Arason, M.Geirsdottir, S. Bogason, K. Kristbergsson// Food Chemistry - 2002. - Vol. 77, p. 377-385.

8. Pighin, D. Effect of salt addition on the thermal behavior of proteins of bovine meat from Argentina / D. Pighin, A. Sancho, C. Gonzalez// Meat Science. - 2008. - Vol. 79(3), p. 549-556.

9. Mourtzinos, I. Thermal oxidation of vanillin affects its antioxidant and antimicrobial properties/I. Mourtzinos, S. Konteles, N. Kalogeropoulos, V.T.Karathanos // Food Chemistry.- 2009. Vol. 114 (3), p. 791-797

10. Zhang, Y. Effects of $\mathrm{NaCl}$ Concentration and Potassium Chloride Substitutions on the Thermal Properties and Lipid Oxidationof Dry-Cured Pork/ Y. Zhang, X. Feng, H.Wu, J.Tang, J. Zhang// Journal of Food Science - 2014. - Vol. 79 (9), p. 1695-1703

11. Marion, Fiala. Der Einsatz der Differential Thermoanalyse (DSC). Teil 2: Zur Festlegung von Zusätzen zu Fleisch/ Karl Otto Honikel, Fiala Marion // Fleischwirtschaft - 1995. - Vol.75(8), p.1013-1018

12. Armenteros, M. Biochemical and sensory changes in drycured ham salted with partial replacements of $\mathrm{NaCl}$ by other chloride salts/ M. Armenteros, M.-C.Aristoy, J. M.Barat, F. Toldra // Meat Science. - 2012. - Vol. 90(2), p. 361-367.

13. Choi, Y. M. Combined effects of potassium lactate and calcium ascorbate as sodium chloride substitutes on the physicochemical and sensory characteristics of low-sodium frankfurte sausage/ Y. M. Choi, K. C. Jung, H. M. Jo , K. W. Nam, J. H.Choe, M. S.Rhee, B. C. Kim// Meat Science. - 2014. Vol. 96(1), p.21-25.

14. Емелина, А.^. Аифференциальная сканирующая калориметрия/А.А. Емелина// Ааборатория химического факультета, МГУ, - 2009. - 42 с.

\section{СВЕДЕНИЯ ОБ АВТОРАХ}

Принадлежность к организации

Туниева Елена Карленовна - кандидат технических наук ведущий научный сотрудник ФГБНУ «ВНИИМП им. В.М. Горбатова», 109316, г. Москва, ул. Талалихина 26.

Тел.: 8(495)676-71-11 e-mail: lenatk@bk.ru

Дедерер Ирина - Dr., Институт Макса Рубнера (MRI), Германия, Институт по исследованию безопасности и качества мяса, Кульмбах, Е.-С.-Baumann-Straße, 20

Тел.: +499221803276 e-mail: irina.dederer@mri.bund.de

\section{Критерии авторства}

Дедерер И. занималась постановкой метода исследования и оптимизацией параметров прибора DSC Q 2000. Туниева Е.К. подготовила план проведения исследований и анализировала полученные данные.

Авторы в равных долях имеют отношение к написанию рукописи и одинаково несут ответственность за плагиат

Конфликт интересов

Авторы заявляют об отсутствии конфликта интересов

Поступила 11.01.2016

\section{REFERENCES}

1. Karunakar, B. Specific heat and thermal conductivity of shrimp meat / B. Karunakar, S.K. Mishra, S. Bandyopadhyay // Journal of Food Engineering. - 1998. - Vol. 37(3), p.345-351.

2. Stabursvik, E. Thermal denaturation of proteins in post rigor muscle tissue as studied by differential scanning calorimetry/ $E$. Stabursvik, H. Martens// Journal of the Science of Food and Agriculture - 1980. - Vol. 31, p. 1034-1042

3. Kijowski, J. M. Effect of sodium chloride and phosphates on the thermal properties of chicken meat proteins/ J. M. Kijowski, M.G. Mast// Journal of Food Science - 1988. - Vol. 53 (2), p. 367-370

4. Graiver, $\mathbf{N}$. Diffusion of sodium chloride in pork tissue/ $\mathbf{N}$. Graiver, A. Pinotti, A.Califano, N. Zaritzki// Journal of Food Engineering. - 2006. - Vol. 77, p. 910-918.

5. Sasaki, K. Differential scanning calorimetry of porcine adipose tissues/ K. Sasaki, M. Mitsumoto, T. Nishioka, M. Irie // Meat Science. - 2006. - Vol. 72(4), p. 789-792.

6. Raemy, A. Behavior of foods studied by thermal analysis: Introduction / A. Raemy// J Thermal AnalCalorimetry. - 2003. Vol. 71(1), p.273-278.

7. Thorarinsdottir, K. A. Changes in myofibrillar proteins during processing of salted cod (Gadusmorhua) as determined by electrophoresis and differential scanning calorimetry / K. A. Thorarinsdottir, S. Arason, M.Geirsdottir, S. Bogason, K. Kristbergsson// Food Chemistry - 2002. - Vol. 77, p. 377-385.

8. Pighin, D. Effect of salt addition on the thermal behavior of proteins of bovine meat from Argentina / D. Pighin, A. Sancho, C. Gonzalez// Meat Science. - 2008. - Vol. 79(3), p. 549-556.

9. Mourtzinos, I. Thermal oxidation of vanillin affects its antioxidant and antimicrobial properties/I. Mourtzinos, S. Konteles, N. Kalogeropoulos, V.T.Karathanos // Food Chemistry.- 2009. Vol. 114 (3), p. 791-797

10. Zhang, Y. Effects of $\mathrm{NaCl}$ Concentration and Potassium Chloride Substitutions on the Thermal Properties and Lipid Oxidationof Dry-Cured Pork/ Y. Zhang, X. Feng, H.Wu, J.Tang, J. Zhang// Journal of Food Science - 2014. - Vol. 79 (9), p. 1695-1703

11. Marion, Fiala. Der Einsatz der Differential Thermoanalyse (DSC). Teil 2: Zur Festlegung von Zusätzen zu Fleisch/ Karl Otto Honikel, Fiala Marion // Fleischwirtschaft - 1995. - Vol.75(8), p.1013-1018

12. Armenteros, M. Biochemical and sensory changes in drycured ham salted with partial replacements of $\mathrm{NaCl}$ by other chloride salts/ M. Armenteros, M.-C.Aristoy, J. M.Barat, F. Toldra // Meat Science. - 2012. - Vol. 90(2), p. 361-367.

13. Choi, Y. M. Combined effects of potassium lactate and calcium ascorbate as sodium chloride substitutes on the physicochemical and sensory characteristics of low-sodium frankfurter sausage/ Y. M. Choi, K. C. Jung, H. M. Jo, K. W. Nam, J. H.Choe M. S.Rhee, B. C. Kim// Meat Science. - 2014. Vol. 96(1), p.21-25. 14. Емелина, А.^. Аифференциальная сканирующая калориметрия/А.А. Емелина// Иаборатория химического факультета, МГУ, - 2009. - 42 с.

\section{AUTHOR INFORMATION}

\section{Affiliation}

Tunieva Elena Karlenovna - $\mathrm{PhD}$ in technical sciences, leading research scientist, The V.M. Gorbatov All-Russian Meat Research Institute, 109316, Moscow, Talalikhina str., 26 Ph: 8 (495) 676-71-11 e-mail: lenatk@bk.ru

Dederer Irina - Dr.-Ing., Max Rubner Institute (MRI), Germany, Department of Safety and Quality of Meat, Kulmbach

D-95326 Kulmbach, E.-C.-Baumann-Straße, 20

Ph: +49 9221803276 e-mail: irina.dederer@mri.bund.de

\section{Contribution}

Dederer I. designed the method of research and optimized the parameters of DSC Q 2000 instrument. Tunieva E.K. prepared the research plan and analyzed the data received.

Authors equally contributed to the writing of the manuscript and are equally responsible for plagiarism.

\section{Conflict of interest}

The authors declare no conflict of interest

Received 11.01.2016 